\title{
PERSEKUSI TERHADAP GEREJA
}

\author{
Adi Putra, M.Th.
}

\begin{abstract}
Abstraksi:
This article explains that persecution is not only happening or experienced by the general public, but it is also experienced by the Lord's Church. This opinion is evidenced by evidence of information obtained from the Bible, especially the New Testament and also in the Church's historical literature. Then discussed further with the church because the church fellowship is different from the world or does not come from the world. Because the Church has been chosen and set apart by God to live differently from the world or live like Christ. And because Christ had already experienced it, then the later Church which is a follower of Christ also experiences similar things. And this writing is endowed with perspectives that have many benefits for the Church. As described above, there are at least five benefits. Such as: the empowerment of the Church may imitate the suffering that Christ has undergone or rather the Church has done the will of Jesus; persuasion helps spread the gospel in the world, persecution of the church can be a means of God to filter and filter out which true believers and non-believers, the quality of the church's faith will be further enhanced through

persecution, and persecution of the church can help the church to bear fruit.
\end{abstract}

\author{
Kata Kunci: \\ Persekusi, Gereja, Dunia
}

\section{Pengantar}

Memasuki pertengahan tahun 2017, media cetak dan media massa di Nusantara diramaikan dengan pemberitaan tentang persekusi. Di mana telah terjadi tindakan semenamena terhadap beberapa oknum atau pun kelompok, hanya karena berbeda pandangan, suku hingga agama. Seperti yang dialami oleh seorang dokter di Solok, Sumatera Barat, yakni dr. Fiera Lovita. Persekusi yang dialami oleh dr. Lovita diawali dengan mengunggah sebuah komentar atau pendapat yang berbeda dengan salah satu ormas di tanah air. Sehingga memicu kemarahan pengikut dan simpatisan ormas tersebut. Seperti dalam pemberitaan Kompas.com tanggal 2 Juni 2017, yang menyatakan,

Tindakan Persekusi berawal saat Fiera membuat tiga status pada akun Facebook-nya pada 19 hingga 21 Mei 2017. Status tersebut dia buat setelah menyaksikan berita konferensi pers pihak kepolisian di televisi terkait tentang kebenaran barang bukti kasus kasus chat WhatsApp Firza Husein dan Rizieq Shihab. "Saya hanya menanggapi berita kaburnya seorang tokoh yang akan diminta keterangannya oleh polisi di Jakarta dalam kasus chat mesum dan kasus hukum lain yang menimpa tokoh tersebut," kata Fiera. Ternyata, ada ormas yang tidak suka dengan status yang diposting Fiera. Pada 22 Mei 2017, sekitar pukul 13.00 waktu setempat, beberapa orang mendatangi Fiera yang tengah berada di dalam mobil bersama kedua anaknya. Mereka mengetuk-ngetuk jendela mobil Fiera. Karena ketakutan, Fiera menghubungi Kanit Intel Polisi Kota Solok bernama Ridwan yang sebelumnya meminta keterangan Fiera terkait status Facebook itu, tanpa menunjukkan surat tugas. Setelah tiba, Ridwan berbicara dengan 
perwakilan dari orang-orang yang mengaku anggota ormas. Saat itu, kata Fiera, anak-anaknya menangis karena ketakutan melihat keberadaan mereka. ${ }^{1}$

Apa yang dialami oleh dr. Fiera ternyata juga dialami oleh seorang remaja berusia 15 tahun berinisial M, di Jakarta Timur. Penyebabnya identik dengan yang dialami oleh dr. Fiera. Seperti yang diberitakan dalam TribunNews.com tanggal 1 Juni 2017, “Tindakan Persekusi itu terjadi karena ia menulis status di akun Facebook-nya yang bernada sindiran terhadap tokoh pimpinan organisasi masyarakat tertentu." "2 Intinya bahwa telah terjadi tindakan yang semenamena terhadap pribadi atau kelompok yang disebabkan karena adanya perbedaan pandangan atau pendapat di depan publik.

Persekusi (bahasa Inggris: persecution) adalah perlakuan buruk atau penganiyaan secara sistematis oleh individu atau kelompok terhadap individu atau kelompok lain, khususnya karena suku, agama, atau pandangan politik. Timbulnya penderitaan, pelecehan, penahanan, ketakutan, dan berbagai faktor lain dapat menjadi indikator munculnya persekusi, tetapi hanya penderitaan yang cukup berat yang dapat dikelompokkan sebagai persekusi. ${ }^{3}$ Bahkan apabila membaca dalam Statuta Roma ${ }^{4}$, persekusi dikategorikan ke dalam salah satu jenis kejahatan kemanusiaan.

Kamus Besar Bahasa Indonesia (KBBI) mendefinisikan arti dari istilah persekusi sebagai pemburuan sewenang-wenang terhadap seorang atau sejumlah warga dan disakiti, dipersusah, atau ditumpas. Istilah ini berasal dari bahasa Inggris, persecution yang juga dapat diartikan sebagai penyiksaan, penganiayaan dan penghambatan.

Setelah melihat beberapa peristiwa persekusi yang telah dijelaskan di atas, dan memperhatikan definisi yang telah diberikan, maka kemudian situasi atau keadaan itu mengingatkan dengan apa yang telah dialami oleh gereja sejak awal hingga sekarang. Bagi gereja, persekusi bukanlah sesuatu yang asing, karena selalu dialami di dalam sejarah perkembangannya. Bahkan tidak keliru apabila dikatakan bahwa Gereja berdiri dan dibangun di atas sisa-sisa persekusi terhadap sebuah gerakan Mesianik yang dipimpin oleh Yesus dari

\footnotetext{
${ }^{1}$ http://nasional.kompas.com/read/2017/06/02/06260541/persekusi.fiera.lovita.diburu.diteror.dan.diinti midasi.// 20/09/2017//.

${ }^{2}$ http://www.tribunnews.com/nasional/2017/06/01/lagi-seorang-remaja-diinterogasi-dan-diancamanggota-ormas-tertentu-gara-gara-statusnya-di-facebook//20/09/2017//.

${ }^{3}$ https://id.wikipedia.org/wiki/Persekusi//27/09-2017//

${ }^{4}$ Statuta Roma Pengadilan Kejahatan Internasional (seringkali disebut sebagai Statuta Pengadilan Kejahatan Internasional atau Statuta Roma) adalah traktat yang mendirikan Pengadilan Kejahatan Internasional (bahasa Inggris: International Criminal Court, disingkat ICC). Statuta tersebut diadopsi di sebuah konferensi diplomatik di Roma pada 17 Juli 1998, dan diterapkan pada 1 Juli 2002. Pada Maret 2016,124 negara menjadi partai untuk statuta tersebut. Pada beberapa pemikiran lainnya, statuta tersebut mendirikan fungsi, yuridiksi dan struktur.
} 
Galilea. Ternyata konflik terbesar yang dihadapi Yesus bukanlah dengan Imperium Romawi, namun dengan masyarakat yang menjadi rahim perjuangannya. Yesus harus mengalami penolakan besar-besaran dari komunitas-komunitas Yahudi, terutama kaum Farisi. Di kampung halamannya sendiri, seperti yang tertulis di dalam Injil Markus, Yesus mengalami penolakan dari warga yang tersinggung oleh karena ada seorang tukang kayu berani-beraninya memberi materi ajaran di sinagoge. Yesus juga mengalami penolakan di kota-kota seperti Betsaida, Kapernaum, dan Dekapolis (Mat. 11:23, Luk. 10:13-15). Secara umum, komunitas Yahudi menolak ajarannya karena menganggap Yesus adalah seorang nabi palsu (false prophet) ${ }^{5}$

Yesus mengklaim berbicara atas nama Tuhan, naskah-naskah, dan karya-karya orang Israel seperti orang-orang Farisi kala itu. Ia juga menghargai simbol-simbol Judaisme dan dianggap penganut agama yang sangat saleh. Lantas apa yang memunculkan persekusi orangorang Yahudi terhadap Yesus Kristus? Gerakan Yesus lebih bersetia pada kenyataan yang direpresentasikan oleh simbol-simbol Judaisme, bukan lambang-lambang kesalehan dan keJudaisme-an yang dijunjung tinggi orang-orang Farisi. Pergerakan yang dilakukan Yesus tidak terobsesi pada pakaian-pakaian yang diperbolehkan, hari-hari yang disucikan, atau makananmakanan yang suci. Yesus tidak terfiksasi pada upaya untuk menjadi orang yang paling saleh atau menjadi orang yang paling Yahudi. Cara Yesus memaknai ke-Yahudi-an ini membuat kedua faksi ini memiliki perbedaan yang radikal. ${ }^{6}$ Dapat dikatakan bahwa hal-hal inilah yang melatarbelakangi terjadinya persekusi terhadap Yesus dan gerakannya.

\section{Persekusi terhadap Gereja Berdasarkan Informasi dari PB}

Dalam Alkitab terjemahan Bahasa Indonesia sama sekali tidak menggunakan istilah ini. Hal yang sangat kontras apabila membaca dalam Alkitab versi Bahasa Inggris. Ternyata istilah persecution muncul berulang-ulang kali dalam Perjanjian Baru. Misalnya dalam Matius 13:21, Markus 4:17, Kisah Para Rasul 8:1, 13:5, 1 Timotius 3:7, Ibrani 10:33, Wahyu 2:10, dan lainlain. $^{7}$

${ }^{5}$ Berger, David; Wyschogrod, Michael. 1978. Jewish and "Jewish Christianity”. New York: KTAV Publishing House. Dan diadaptasi dalam artikel Persekusi dan Bahaya Menapaki Jalan Kristus: Sebuah refleksi terhadap Penyerbuan Kantor YLBHI, yang ditulis oleh Dono Ekuator. Sumber: https://indoprogress.com/2017/09/persekusi-dan-bahaya-menapaki-jalan-kristus-sebuah-refleksi-terhadappenyerbuan-kantor-ylbhi//27/09/2017//

${ }^{6}$ Persekusi dan Bahaya Menapaki Jalan Kristus: Sebuah refleksi terhadap Penyerbuan Kantor YLBHI, yang ditulis oleh Dono Ekuator. Sumber: https://indoprogress.com/2017/09/persekusi-dan-bahaya-menapakijalan-kristus-sebuah-refleksi-terhadap-penyerbuan-kantor-ylbhi//27/09/2017//

${ }^{7}$ Dalam penelitian ini hanya akan dibahas ayat-ayat ini. Meskipun istilah persekusi dalam bentuk yang berbeda juga muncul dalam ayat atau perikop yang lain. 
Matius 13:21. Ayat ini (13:21) merupakan satu bagian yang utuh dari perikop yang panjang pengajaran Tuhan Yesus tentang perumpamaan seorang penabur (13:1-23). Apabila membaca dalam terjemahan dalam Bahasa Indonesia ${ }^{8}$ memang tidak akan dijumpai istilah persekusi. Oleh karena dalam terjemahan Bahasa Indonesia lebih memilih menggunakan istilah penganiayaan (ITB dan BIMK).

Hal yang berbeda dijumpai dalam terjemahan Bahasa Inggris, baik untuk versi New International Version (NIV/2011) dan juga New American Standard Bible (NAS/1977), hingga terjemahan Bahasa Inggris yang lain seperti King James Version (KJV/1611/1769) yang sepakat untuk memberikan menggunakan istilah persecution.

Lalu, istilah Yunani apakah yang diterjemahkan dengan persecution atau penganiayaan?

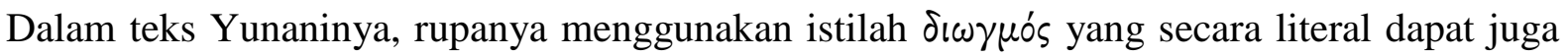
diartikan dengan pursuit, chase atau pengejaran (penjahat), mengusir, menghalau pergi, atau menghalau pergi. Bagaimana memahaminya dalam konteks Matius 13:1-23?

Apabila memperhatikan konstruksi kalimat dalam Matius 13:21, maka di sana dapat dipahami bahwa persekusi yang dialami oleh orang Kristen atau Gereja merupakan salah satu bentuk penindasan. Itulah sebabnya seringkali $\ddot{\eta}$ dalam ayat tersebut diterjemahkan dengan atau. Hal itu memberikan penegasan yang cukup kuat bahwa penindasan-penindasan yang dialami oleh Gereja salah satunya adalah persekusi. Dalam Matius 13:21, untuk kata penindasan menggunakan istilah thlipsis, di mana kata ini digunakan hanya 4 kali dalam Injil Matius. Kata ini seringkali digunakan untuk menyatakan tekanan yang besar dan dipakai, misalnya untuk menginjak-injak anggur sampai pecah. Kata thlipsis biasanya dikaitkan dengan kata diōgmos (kata ini hanya muncul sekali dalam Injil Matius, dan hanya 10 kali dalam PB). Biasanya kata diōgmos menunjuk kepada kesulitan yang dialami oleh pengikut Kristus, yakni penganiayaan. ${ }^{9}$ Kata ini hendak menegaskan bahwa tidak ada jalan yang mudah bagi gerejagereja Tuhan. Konsekuensi iman percaya kepada Yesus Kristus adalah kita dibenci oleh dunia, kita dianiaya oleh dunia.

Dampak yang ditimbulkan oleh persekusi dalam perikop ini adalah membuat orang Kristen "tidak berakar" dan "tahan sebentar" atau murtad. Dalam pengertian,persekusi dapat

\footnotetext{
${ }^{8}$ Matius 13:21, "Tetapi ia tidak berakar dan tahan sebentar saja. Apabila datang penindasan atau penganiayaan karena firman itu, orang itupun segera murtad"(ITB). Hal yang serupa pun dijumpai dalam terjemahan Bahasa Indonesia dalam versi yang lain, seperti: "Tetapi kabar itu tidak berakar dalam hati mereka, sehingga tidak tahan lama. Begitu mereka menderita kesusahan atau penganiayaan karena kabar itu, langsung mereka murtad" (BIMK).

${ }^{9}$ Leon Morris, Injil Matius, Surabaya: Momentum, 2016, hlm. 354.
} 
menyebabkan orang Kristen untuk meninggalkan iman karena tidak ingin terlibat atau mengalami kesulitan, penderitaan bahkan penganiayaan.

Kisah Para Rasul 8:1. Konteks bagian ini adalah penganiayaan yang sedang dialami oleh gereja yang baru saja lahir melalui hari Pentakosta. Pascakelahirannya, gereja diperhadapkan dengan persekusi yang hebat. Bahkan tidak sedikit orang Kristen yang dianiaya hingga mati hanya karena senantiasa bertahan atau mempertahankan iman percaya mereka kepada Tuhan Yesus. Salah seorang diantaranya adalah Stefanus.

Menurut Marshall, "The fact that the apostles, "could stay on in Jerusalem (no doubt along with other Christians) confirms the suspicion that it was mainly Stephen's group which was being attacked." ${ }^{10}$ Marshall melihat ada sebuah indikasi yang kuat bahwa sebenarnya secara umum yang mengalami persekusi pada waktu itu juga merupakan kelompok Stefanus. Bahkan ditambahkan oleh Fernando, bahwa "the death of Stephen gives a new impetus to the antiChristian forces with which Saul is now prominently associated (8:1a)". ${ }^{11}$ Maksudnya, kematian Stefanus seolah-olah memberikan "angin segar" bangkitnya kelompok yang memang tidak suka dengan orang-orang Kristen.

Pada konteks Kisah Para Rasul, persekusi memang dilihat dalam perspektif konflik agama. Mengapa? Oleh karena semenjak pengikut-pengikut Kristus semakin bertambah jumlahnya, membuat agama induk atau agama Yahudi merasa terancam. Itulah sebabnya, tokoh seperti Saulus (Paulus) kemudian mendedikasikan segenap tenaganya untuk melakukan persekusi terhadap gereja. Meskipun pada akhirnya, dia menjadi pengikut Kristus yang setia, bahkan mati karena mengalami persekusi dari penguasa yang sedang berkuasa pada waktu itu.

1 Tesalonika 3:7. Adapun bunyi ayat ini adalah "Maka kami juga, saudara-saudara, dalam segala kesesakan dan kesukaran kami menjadi terhibur oleh kamu dan oleh imanmu". Kata kesukaran dalam TB dalam versi Inggrisnya, khususnya NIV menggunakan istilah persecution. Sebenarnya dalam ayat ini hendak menegaskan bahwa Paulus menganggap kabar baik tentang jemaat di Tesalonika cukup menghiburnya dengan kesusahan yang dia juga sedang hadapi. Meskipun bagi Paulus sangat mudah untuk untuk menanggung penderitaan, atau penganiayaan, atau pertengkaran-pertengkaran dari luar, apabila dia ternyata mendapati pelayanannya berhasil dengan baik dan orang-orang yang sudah ia pertobatkan menjadi Kristen yang tetap teguh. ${ }^{12}$

${ }^{10}$ Ajith Fernando, The NIV Application Commentary: Acts (From Biblical text..to Contemporary life), Zondervan, Grand Rapids, Michigan, 2009, hlm. 262.

${ }^{11}$ Ajith Fernando, hlm. 262.

${ }^{12}$ Matthew Henry, Tafsiran Surat 1 dan 2 Tesalonika, Surabaya: Momentum, 2015, hlm. 458. 
Bahkan apabila membaca dalam 1 Tesalonika 2:14-16 memberikan indikasi yang cukup kuat bahwa orang-orang Yahudi-lah yang memusuhi mereka, sehingga mereka hidup dalam penderitaan dan kesusahan yang hebat. Itulah sebabnya Paulus sangat murka dan marah kepada orang-orang Yahudi, seperti yang dikemukakan berikut ini,

(1)Mereka telah membunuh Tuhan Yesus, dan dengan lancing dan pongah menghendaki supaya darah-Nya ditanggungkan atas mereka dan anak-anak mereka; (2) Mereka telah membunuh nabi-nabi mereka sendiri (KJV). Demikianlah yang mereka lakukan sejak semula. Nenek moyang mereka telah melakukannya. Mereka menjadi keturunan penganiaya; (3)Mereka membenci rasul-rasul, dan telah melakukan terhadap rasul-rasul itu segala kejahatan semampu yang dapat mereka lakukan. Mereka menganiaya para rasul, dan mendesak dan mengejar mereka dari satu tempat ke tempat lain. Dan karena mereka membunun Tuhan Yesus, maka tidaklah mengherankan jika mereka juga menganiaya para pengikutnya; (4)Apa yang berkenan kepada Allah tidak mereka pedulikan...; (5)Semua manusia mereka musuhi...; (6)Mereka memiliki rasa permusuhan yang sangat keras terhadap bangsa-bangsa lain, dan cemburu karena Injil ditawarkan kepada bangsa-bangsa lain.... ${ }^{13}$

Intinya, karena orang-orang Yahudi menganiaya atau menjadi aktor dibalik penganiayaan serta penderitaan yang dialami oleh jemaat di Tesalonika, maka membuat Paulus kemudian mencela orang Yahudi karena telah melawan Injil dan berkata bahwa murka Allah telah menimpah mereka. Murka Allah itu dapat meliputi tentang Allah telah menyerahkan orang Yahudi yang berhati keras ke dalam kebutaan yang sia-sia (bdk. Rm. 1:21) maupun pencurahan murka-Nya di masa depan yang dinubuatkan oleh Kristus sendiri dalam kitab Injil.

Namun dari pihak jemaat Tuhan di Tesalonika tidak boleh menganggap dan melihat kesulitan dan penderitaan karena persekusi sebagai sesuatu yang asing dalam kehidupan Kristen. Oleh karena: (1) Gereja yang sejati yang menolak untuk menyesuaikan diri dengan sifat yang berlaku dalam dunia di sekitarnya akan mengalami kesusahan (3:4). (2) Persekusipersekusi itu tidak boleh dianggap sebagai pencurahan murka Allah atas orang fasik pada akhir zaman (5:9).

Dengan demikian dalam konteks jemaat Tesalonika, persekusi yang dialami oleh gereja di sana merupakan bentuk konflik agama. Karena persekusi itu berasal dari orang-orang Yahudi yang dalam surat ini disebut Paulus, hati mereka sudah dipenuhi oleh kejahatan. Namun satu hal yang perlu digarisbawahi bahwa persekusi merupakan konsekuensi yang harus dialami oleh setiap orang percaya karena telah percaya kepada Tuhan Yesus.

Ibrani 10:32-33. Dua ayat di atas bunyinya sebagai berikut, "Ingatlah akan masa yang lalu. Sesudah kamu menerima terang, kamu banyak menderita oleh karena kamu bertahan

\footnotetext{
${ }^{13}$ Henry, hlm. 448-49.
} 
dalam perjuangan yang berat, baik waktu kamu dijadikan tontonan oleh cercaan dan penderitaan, maupun waktu kamu mengambil bagian dalam penderitaan mereka yang diperlakukan sedemikian". Dari kedua ayat di atas, Henry memberikan komentarnya dengan mengatakan, "Pada masa permulaan Injil, timbul penganiayaan yang sangat bengis terhadap orang-orang yang mengakui agama Kristen, dan orang-orang Ibrani yang percaya juga pernah mengalaminya". ${ }^{14}$ Dan berdasarkan kedua ayat di atas, penulis Surat Ibrani kembali mengingatkan mereka dua hal, yakni: (1) Kapan mereka telah menderita dan (2)Apa yang sudah mereka derita.

Mereka telah menderita di masa yang lalu, sesudah mereka menerima terang. Maksudnya apa? Maksudnya adalah bahwa segera setelah Allah menghembuskan nafas hidup ke dalam jiwa mereka, dan menyatakan terang ilahi dalam pikiran mereka, dan membawa mereka ke dalam perkenanan dan perjanjian-Nya. Keadaan alami adalah keadaan yang gelap, dan mereka terus dalam keadaan itu tidak akan diganggu oleh Iblis dan dunia. Tetapi keadaan anugerah adalah keadaan terang, dan karena itu kuasa-kuasa kegelapan akan menentangnya dengan keras. Itulah sebabnya, orang yang mau hidup saleh dalam Kristus Yesus harus dan pasti menderita penganiayaan atau persekusi.

Ada begitu banyak penderitaan yang dialami oleh setiap orang Kristen, seperti: (1) Mereka menderita dalam diri mereka; dan (2) Mereka menderita dalam penderitaan saudarasaudara mereka. Dalam konteks penderitaan pribadi, mereka menjadi tontonan, bahan pertunjukan dunia. Bahkan mereka menderita dalam nama baik mereka, oleh karena begitu banyaknya cercaan yang ditimpahkan kepada mereka. Bahkan tidak sedikit dari orang Kristen harus kehilangan harta mereka, itulah sebabnya mereka juga menderita dalam harta milik mereka.

Selanjutnya penderitaan bagi saudara-saudara hendak menegaskan bahwa Roh orang Kristen adalah roh yang berbela rasa, bukan roh yang egois - melainkan roh belas kasihan. Itulah sebabnya penderitaan sesama Kristen di tempat lain juga kemudian menjadi penderitaan kita. Atau kita pun turut merasakan kepedihan, penderitaan yang mereka alami. Itu yang dimaksud dengan ungkapan bahwa orang Kristen adalah satu tubuh, digerakkan oleh satu roh, berangkat dari satu kepentingan bersama, dan anak-anak dari Allah yang menderita dalam segala penderitaan umat-Nya.

\footnotetext{
${ }^{14}$ Matthew Henry, Tafsiran Surat Ibrani, Surabaya: Momentum, 2016, hlm. 178.
} 
Dengan demikian, persekusi yang dialami oleh orang Kristen dalam konteks Ibrani merupakan persekusi yang seharusnya menyadarkan kita semua bahwa kita adalah satu. Sehingga kemudian membuat kita merasa perlu untuk saling membantu dan menanggung setiap penderitaan yang dialami oleh setiap orang Kristen. Persekusi dapat dipahami dalam dua konteks yakni yang bersifat pribadi dan bersama-sama.

Wahyu 2:10. Bunyi ayat ini adalah, "Jangan takut terhadap apa yang harus engkau derita! Sesungguhnya Iblis akan melemparkan beberapa orang dari antaramu ke dalam penjara supaya kamu dicobai dan kamu akan beroleh kesusahan selama sepuluh hari. Hendaklah engkau setia sampai mati, dan Aku akan mengaruniakan kepadamu mahkota kehidupan". Mungkin yang menjadi pertanyaan kita adalah apa maksud dari persekusi selama sepuluh hari?

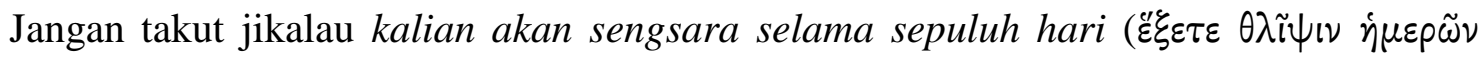
$\left.\delta \varepsilon^{\prime} \chi \alpha\right)$. Kata $\varepsilon^{\prime} \xi \varepsilon \tau \varepsilon$ yang merupakan indikatif future secara sederhana tense futurenya fokus pada unsur antisipasi: ini akan dibatasi sepuluh hari. Frasa sepuluh hari digunakan untuk sesuatu yang tidak tentu tetapi periode waktu yang relatif pendek.. tetapi sepuluh juga berfungsi sebagai sebuah bilangan yang menggambarkan kesempurnaan. ${ }^{15}$ Hal ini dipertegas oleh Kistemaker, “ Di Kitab Wahyu, sepuluh berarti penuh dalam system desimal. Angka ini adalah simbol bagi lengkapnya periode penderitaan, yang bukannya lama atau singkat tetapi penuh, karena akhirnya sudah pasti”. ${ }^{16}$

Karena semua penderitaan atau pun kesengsaraan yang dialami oleh orang Kristen di Smirna digunakan untuk menguji iman atau kesetiaan mereka kepada Tuhan, maka kesengsaraan itupun harus dipahami sebagai sebuah kesengsaraan yang sempurna - bukan kesengsaraan yang biasa-biasa saja. Bahkan nyawa mereka adalah taruhannya. Seperti yang Polikarpus telah tunjukkan, di mana nyawanya dikorbankan demi kesetiaan kepada Tuhan Yesus.

Lalu penderitaan seperti apa yang dialami oleh jemaat di Smirna? Untuk menegaskan tentang kesengsaraan atau kesusahan jemaat di Smirna, Rasul Yohanes menggunakan kata $\theta \lambda \tilde{\imath} \psi \iota \varsigma$ dalam bentuk akusatif tunggal, yakni: $\theta \lambda \tilde{\imath} \psi \iota v$. Menurut Bauer-Danker, kata $\theta \lambda \tilde{\imath} \psi \iota \varsigma$ menegaskan bentuk kesusahan yang memberikan keadaan yang sukar, penindasan atau tekanan, penderitaan, dan kesengsaraan. Kondisi yang sama ditegaskan dalam Kisah Para

\footnotetext{
${ }^{15}$ David E Aune. Word Biblical Commentary: Revelation 1-5. Dallas: Thomas Nelson, 1997, hlm. 166.

${ }^{16}$ Simon J. Kistemaker, Tafsiran Kitab Wahyu. Surabaya: Momentum, 2009, hlm. 134.
} 
Rasul 11:19; Roma 5:3b; 12:12, dsb.. ${ }^{17}$ Ditambahkan oleh Kistemaker, "Kesusahan berarti hidup dalam penganiayaan dan kesulitan yang menghimpit. Yang satu yang menghasilkan yang lain: penganiayaan menghasilkan kemiskinan karena pekerjaan dan sumber-sumber kehidupan jemaat dirampas. Orang percaya di Smirna mungkin telah mengalami penyitaan harta benda". ${ }^{18}$ Artinya, jemaat di Smirna merupakan korban diskriminasi, ketidakadilan, hak mereka dikebiri, bahkan harta milik mereka dirampas; sehingga mereka berada dalam kesengsaraan.

\section{Persekusi terhadap Gereja dalam Sejarah Gereja}

Ketika orang-orang yang mengklaim diri sebagai pengikut Kristus semakin bertambah secara masiv, maka mereka pun mulai diperhadapkan dengan berbagai bentuk ujian, termasuk salah satu di antaranya adalah penganiayaan atau yang dalam tulisan ini disebut persekusi. Memasuki abad ke-2 Masehi pekabaran Injil sudah menyebar ke berbagai penjuru, seperti yang dikemukakan Th. van den End,

Sekitar tahun 180 M., agama Kristen sudah tersebar ke daerah yang membentang dari Gallia (Perancis) di barat sampai Arabia Selatan dan Persia di timur. Orang-orang Kristen paling banyak terdapat di Mesopotamia Utara, Siria, Asia Kecil, dan di Afrika Utara (daerah Tunisia sekarang)... Agama Kristen sudah memasuki berbagai lingkungan kebudayaan dan bahasa. ${ }^{19}$

Intinya, dari pernyataan van den End di atas dapat kemudian disimpulkan bahwa memang kekristenan sudah tersebar ke berbagai tempat. Akan tetapi perjumpaannya dengan budaya atau keperyaan bahkan keyakinan yang berbeda dengannya dapat menimbulkan konflik (agama). Hal ini sangat dimungkinkan karena adanya perbedaan ajaran ataupun kepentingan kelompok masing-masing.

Contoh yang cukup familiar bagi kita adalah perjumpaan agama Yahudi dengan agama Kristen. Meskipun mungkin dalam konteks ini tidak bisa juga untuk disebut sebagai perjumpaan, karena memang kekristenan dapat dikatakan "pecahan" dari agama Yahudi. Akan tetapi seiring berjalannya waktu dapat dilihat bahwa ternyata terjadi konflik di antara kedua agama itu. Kondisi itu dapat dengan jelas dibaca dalam Kisah Para Rasul. Sejak zaman Paulus belum bertobat, ditandai dengan dirajamnya Stepanus oleh orang-orang yang menyebut diri sebagai orang-orang Yahudi. Seperti yang dicatat dalam Kisah Para Rasul 7: 54-60,

\footnotetext{
${ }^{17}$ Bauer's, Walter. A Greek-English Lexicon of The New Testament And Other Early Christian Literature (BDAG) Third Edition. Chicago: The University of Chicago Press, 2000. Diedit oleh: Frederick William Danker, hlm. 457.

${ }^{18}$ Kistemaker 2009, hlm.132. hlm. 19.

${ }^{19}$ Th. Van den End, Harta Dalam Bejana: Sejarah Gereja Ringkas, Jakarta: BPK Gunung Mulia, 2010,
} 
Ketika anggota-anggota Mahkamah Agama itu mendengar semuanya itu, sangat tertusuk hati mereka. Maka mereka menyambutnya dengan gertakan gigi. Tetapi Stefanus, yang penuh dengan Roh Kudus, menatap ke langit, lalu melihat kemuliaan Allah dan Yesus berdiri di sebelah kanan Allah. Lalu katanya: "Sungguh, aku melihat langit terbuka dan Anak Manusia berdiri di sebelah kanan Allah." Maka berteriak-teriaklah mereka dan sambil menutup telinga serentak menyerbu dia. Mereka menyeret dia ke luar kota, lalu melemparinya. Dan saksi-saksi meletakkan jubah mereka di depan kaki seorang muda yang bernama Saulus. Sedang mereka melemparinya Stefanus berdoa, katanya: "Ya Tuhan Yesus, terimalah rohku." Sambil berlutut ia berseru dengan suara nyaring: "Tuhan, janganlah tanggungkan dosa ini kepada mereka!" Dan dengan perkataan itu meninggallah ia.

Bahkan kalau dibaca dalam Kisah Para Rasul, maka di sana para rasul yang begitu giat memberitakan Injil berulang kali keluar-masuk penjara karena Injil. Penguasa pada zaman itu berusaha menekan supaya gereja tidak dapat bertumbuh hingga besar. Bahkan kalau bisa supaya gereja dapat “dimatikan”. Bahkan Rasul Paulus yang sebelumnya menjadi actor persekusi terhadap gereja, setelah bertobat juga pernah mengalami bagaimana rasanya diusir, dihina, hingga dipenjarakan hanya karena Injil Kristus yang harus diberitakan kepada bangsabangsa lain. Dan apabila kita membaca tradisi tentang pelayanan dan sejarah misi yang dikerjakan oleh Paulus, maka diperoleh informasi bahwa Paulus mati juga karena Injil.

Kekristenan tidak hanya mendapat persekusi dari kelompok yang berseberangan dengan kekristenan, akan tetapi ternyata juga mengalami persekusi dari penguasa atau pemerintah yang sedang berkuasa pada waktu itu. Van den End mengatakan, "Pejabat-pejabat negara tidak begitu percaya kepada fitnaan dungu itu. Tetapi mereka mencurigai sikap politis orang-orang Kristen. Maklumlah mereka ini menolak menyatakan kesetiaannya kepada negara dengan membakar dupa di muka patung kaisar, seperti yang dilakukan oleh semua rakyat". ${ }^{20}$

Oleh karena orang Kristen tidak mau menyembah kepada kaisar atau patung kaisar, maka kemudian hal itu menjadi pemicu kekaisaran Romawi membenci dan kemudian menganiaya setiap orang Kristen (baca: Gereja). Dan seperti yang dikemukakan oleh Van den End bahwa itulah yang melatarbelakangi terjadinya penganiayaan (persekusi) terhadap orang Kristen selama dua setengah abad. ${ }^{21}$

Bahkan seringkali banyak kejadian-kejadi yang dipolitisasi atau dibuat sedemikian rupa guna nanti dapat kemudian mempersalahkan orang-orang Kristen yang ada di kota itu. “Apabila ada kebakaran, kelaparan, banjir menimpa sesuatu kota, penduduknya berteriak: Orang-orang Kristen yang bersalah! Biarlah mereka dilemparkan ke binatang buas saja! Lalu

\footnotetext{
${ }^{20}$ Th. Van den End, hlm. 49.

${ }^{21}$ Bandingkan van den End, hlm. 49.
} 
rumah-rumah orang-orang Kristen didatangi, dan mereka diseret ke pengadilan gubernur ( $b d k$. Kis. 18:2; 19:29)".22

Bahkan jauh sebelum itu, tepatnya pada tahun 64 M., atas perintah kaisar Nero (54-68). Ia menyalahkan orang-orang Kristen telah menyalahkan api besar yang memusnahkan sebagian besar kota itu, sebab rakyat sudah mulai mencurigai bahwa Nero sendirilah yang telah memerintahkan melakukan pembakaran tersebut. Sehingga orang Kristen dianiaya dengan sangat hebat. Pada abad kedua berikutnya, banyak tokoh-tokoh yang terkemuka dalam gereja mati martir dalam persekusi yang juga dilakukan oleh pemerintah yang berkuasa pada masa itu. Seperti yang juga dikemukakan oleh van den End bahwa, "Igantius, uskup Antiokhia (Siria), Polikarpus, uskup Smirna (Asia Kecil), Blandina, seorang budak perempuan dari kota Lyon (Perancis), dan lain-lain. Siksa yang keji pun tidak menggentarkan mereka, malah orangorang martir itu bergembira dengan penuh syukur kepada Tuhan karena mereka dipandang layak mendapat bagian dalam kematian Kristus sendiri". ${ }^{23}$

Masih menurut informasi dari van den End, dia mengatakan, "Sekitar tahun 250 mulailah tahap kedua dari penghambatan itu. Negara sendiri menjadi pemrakarsa penganiayaan dan berusaha secara sistematis untuk memusnahkan agama Kristen. Kaisar Decius ${ }^{24}$ (+/- 250) dan Kaisar Diocletianus (+/- 300) adalah musuh-musuh utama agama Kristen". ${ }^{25}$ Decius berusaha memulihkan kembali keadaan Kerajaan Romawi seperti pada zaman Kaisar Agustus, termasuk di bidang keagamaan. Decius ingin menghidupkan kembali agama Roma Kuno. Oleh karena komunitas Kristen menentang usaha itu, ia melihat orang Kristen sebagai penghambat. Pada tahun 250, dia mengeluarkan keputusan untuk mengadakan penghambatan bagi agama Kristen. Dan sasaran penghambatan itu adalah para uskup. Beberapa tokoh Kristen yang mati karena sistem penghambatan agama Kristen yang dilakukan oleh kaisar Decius, antara lain: (1) Fabianus, uskup Roma; (2) Babylas, uskup Antiokhia; dan (3) Alexander, uskup Yerusalem. ${ }^{26}$

Kemudian persekusi yang dilakukan oleh Diocletianus kepada orang Kristen (baca: Gereja) dikategorikan sebagai penganiayaan yang besar merupakan penganiayaan atau

${ }^{22}$ Th. Van den End, hlm. 49.

23 Ibid., hlm. 50.

${ }^{24}$ Decius, nama lengkapnya adalah Mecius Qointus Decius adalah seorang kaisar Romawi pada abad ke3 M. Dia memulai karirnya sebagai seorang tentara Romawi. Kariernya dalam ketentaraan Romawi semakin naik ketika dia diangkat menjadi seorang jenderal pada masa pemerintahan Kaisar Pilipus. Pada tahun 248, ia mendapat tugas untuk memadamkan pemberontakan suku bangsa Goth oleh kaisar Pilipus dan berhasil melaksanakannya. Setelah itu, pasukannya mengangkat Decius sebagai kaisar Roma, dan Decius pun berbalik menyerang kota Roma. Pada pertempuran di Verona, kaisar Pilipus terbunuh, dan Decius pun diangkat sebagai Kaisar Romawi yang sah mulai tahun 249.

${ }^{25}$ Ibid., hlm. 50-51.

${ }^{26}$ F.D. Wellen, Riwayat Singkat Tokoh-tokoh Gereja. Jakarta: BPK Gunung Mulia, 1993, hlm. 89-90. 
penindasan terakhir dan paling berat terhadap umat Kristen yang dilakukan oleh kekaisaran Romawi. Bahkan pada tahun 303, Kaisar Diocletianus, Maximianus, Galerius, dan Konstantius mengeluarkan serangkaian edik atau dekrit untuk mencabut hak hukum umat Kristen dan meminta agar mereka mengikuti praktik-praktik keagamaan Romawi tradisional. Edik-edik berikutnya menyasar kaum klerus dan memerintahkan semua penduduk untuk mempersembahkan kurban kepada para dewa Romawi (sebuah kebijakan yang dikenal sebagai kurban universal).

Akan tetapi setelah pada tahun 313, pada masa pemerintahan kaisar Konstantinus Agung mengeluarkan dekrit yang kemudian dikenal dengan nama Edik Milano. Dalam keputusan ini, kaisar memberikan kebebasan pada rakyatnya dalam beragama dan beribadah. Orang Kristen yang pada awalnya selalu dianiaya dan terdiskriminasi memperoleh haknya untuk berkembang dan diakui, bahkan nantinya pada tahun 380 menjadi agama resmi (Kristen Ortodoks) yang merupakan keputusan penerus dari Konstantinus, yaitu Kaisar Theodosius. ${ }^{27}$ Setidaknya keputusan ini dapat memberikan kelegaan untuk sementara waktu bagi orang-orang Kristen atau Gereja pada masa itu.

\section{Persekusi terhadap Gereja di Indonesia}

Setelah mendeskripsikan bagaimana persekusi yang dialami oleh gereja mulai awal kemunculannya hingga menjelang abad ke-4 M., seperti informasi yang diperoleh dari teksteks PB hingga dari literatur-literatur sejarah gereja. Di mana berdasarkan informasi yang telah dikemukakan di atas, maka dapat dilihat dengan jelas betapa penghambatan, penganiayaan, diskriminasi bahkan persekusi betul-betul terjadi dan dialami oleh gereja. Sumber persekusi terhadap gereja bermacam-macam, seperti: dari pemerintah yang sedang berkuasa, tetapi juga dari agama Yahudi sebagai agama induk kekristenan. Dan hampir seluruh gereja di seluruh tempat, dan di sepanjang abad, mengalami persekusi dan tanpa terkecuali gereja di Indonesia.

Sebagai negara majemuk atau negara yang mengakui lebih dari satu agama, maka konflik horisontal antara penganut agama yang berbeda seringkali tidak dapat dihindarkan. Bahkan konflik agama sudah sangat sering terjadi di negeri ini. itulah sebabnya, bangsa Indonesia seringkali dicap sebagai bangsa yang tidak aman bagi perbedaan agama. "Indonesia telah dimintai keterangan terkait maraknya kasus pelanggaran kebebasan beragama dan

\footnotetext{
${ }^{27}$ Motivasi Konstantinus Agung mengeluarkan keputusan ini adalah karena perpecahan politik yang sedang terjadi di Romawi. Saat itu terjadi perang saudara selama lebih dari setengah abad. Dengan keputusan tersebut, dia melihat bahwa kekuatan agama Kristen sanggup mempersatukan berbagai kekuatan yang berselisih saat pemerintahannya. Edik Milano juga dianggap merupakan titik balik sejarah di Eropa dalam hal kebebasan peradaban. Kemerdekaan dan jaminan kepada rakyat dalam berdemokrasi sesuai dengan prinsip-prinsipnya menjadi diakomodasi oleh negara.
} 
berkeyakinan dalam sidang berkala Dewan HAM PBB di Jenewa Swiss 23 Mei 2012. Laporan SETARA Institute terakhir menyebutkan tahun 2011 lalu terjadi 244 kasus pelanggaran kebebasan beragama dan berkeyakinan dengan 299 bentuk tindakan kekerasan. SETARA juga mengungkapkan bahwa Front Pembela Islam (FPI) dan Majelis Ulama Indonesia (MUI) adalah dua organisasi sebagai aktor non-negara yang paling banyak melakukan tindakan pelanggaran kebebasan beragama dan berkeyakinan". 28

"Pemerintah Indonesia dianggap gagal menjaga toleransi antar umat beragama, ketika kasus-kasus kekerasan atas nama agama terus berlangsung hingga kini. Pada Desember 2011, ketika sebagian besar umat kristiani di dunia merayakan Natal di gereja, para jemaat Gereja Kristen Indonesia (GKI) Yasmin, Bogor, harus 'kehilangan' tempat ibadahnya. Dibayangbayangi teror kekerasan oleh kelompok penentangnya, mereka akhirnya menggelar ibadah di trotoar, tak jauh dari bangunan gereja milik mereka yang disegel oleh Pemerintah Daerah (Pemda) Bogor, atas desakan beberapa ormas agama. Memang Natal kali ini ironis bagi mereka. Di negara demokratis, yang memberi kebebasan, tetapi kenyataannya semua jalur formal yang mereka tempuh, tetapi mereka (tetap) tidak bisa berbuat apa-apa. Negaralah yang harus bertindak, Karena, bagaimanapun juga, kita berpatokan pada prinsip hak asasi manusia yang universal". 29

Berulangnya kasus-kasus penutupan dan pengrusakan tempat ibadah, hingga pengusiran kelompok minoritas, merupakan fakta yang mengindikasikan pemerintah tidak bisa bersikap tegas terhadap kelompok-kelompok pelaku kekerasan.

Bahkan apabila memperhatikan informasi yang diperoleh dari website Gereja Bethel Injil Sepenuh (GBIS), di mana memuat informasi tentang penutupan gereja sejak tahun 1945-1997 dengan jumlah yang sangat mencengangkan. Di sana dikatakan, "Sejak tahun 1945 s/d 1 Juli 1997 telah ditutup/dirusak/dibakar 374 gedung Gereja dan paling sedikit 20 orang rohaniwan atau pemuka agama Kristen yang telah meninggal". ${ }^{30}$ Bahkan situasi yang dialami oleh gereja pada periode itu cukup memprihatinkan, seperti yang dikemukakan berikut ini,

Sejak permulaan tahun 1996, terutama umat Kristiani Indonesia dihadapkan dengan sederetan peristiwa yang mengejutkan. Selain itu, terdapat usaha-usaha pembatasan ruang gerak, penghasutan, intimidasi dan diskriminasi terhadap golongan masyarakat yang lemah untuk tujuan tertentu oleh oknum-oknum yang tidak bertanggung jawab. Umat Kristiani disudutkan dan ada yang menuduh mengkhianati Negara dan bangsa

\footnotetext{
${ }^{28} \mathrm{http} / /$ www.radioaustralia.net.au/indonesian/radio/onairhighlights/marak-kasus-kekerasan-atas-namaagama-indonesia-dilaporkan-ke-pbb/944098//14/10/2017//

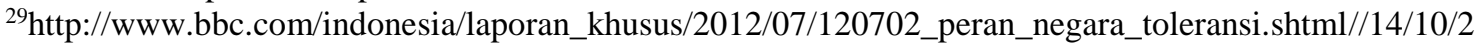
$017 / /$

${ }^{30} \mathrm{http}$ //gbis-online.org/gbis/online/berita-119-penutupan-pengrusakan-dan-atau-pembakaran-374-gerejadi-indonesia-tahun-1945--1997.html//14/10/2017///
} 
Indonesia. Umat Kristiani dianggap tidak mempunyai andil dalam perjuangan bangsa. Dilecehkan bahwa umat Kristiani penganut agama kolonial dan agama orang kafir. Demikian hasutan-hasutan yang selalu dikumandangkan sampai saat ini. ${ }^{31}$

Intinya, gereja mengalami tindakan kekerasan, ketidakadilan, dan aniaya dari kelompok mayoritas yang juga didukung oleh sikap apatis dan diam dari pemerintah, sehingga membuat gereja berada pada posisi dipojokkan bahkan dilecehkan. Orang Kristen dianggap penganut agama kolonial bahkan sering juga disebut agama kafir. Inilah bentuk-bentuk persekusi yang dialami oleh gereja pada periode ini sebagai bentuk konflik agama antara kekristenan dengan agama-agama di luar kekristenan terutama dengan agama Islam.

Tidak sampai di situ, bahkan pada tahun 2011 juga terjadi pengrusakan dan pembakaran gereja di Temanggung. "Setidaknya tiga gereja di Temanggung, Jawa Tengah, rusak karena menjadi sasaran amuk massa menyusul kerusuhan dalam persidangan kasus penistaan agama dengan terdakwa Antonius Richmond Bawengan di Pengadilan Negeri Temanggung, Selasa, 8 Februari 2011. Gereja Bethel Indonesia yang berjarak sekitar dua kilometer dari Pengadilan Negeri Temanggung mengalami kerusakan akibat pembakaran oleh kelompok massa tersebut. Sebuah bangunan sekolah Taman Kanak-kanak (TK) yang berada di lingkungan gereja terbakar pada sejumlah bagian. Termasuk enam unit motor hangus terbakar akibat insiden tersebut. Selain itu, pembakaran juga terjadi di Gereja Pantekosta Temanggung. Belum diperoleh laporan mengenai dampak pembakaran di gereja tersebut. Sementara itu, Gereja Katolik Santo Petrus dan Paulus juga sempat dirusak massa. Bagian depan gereja rusak dilempari batu". 32

Pada bulan Oktober 2015, juga terjadi pembakaran gereja di Aceh. Informasi ini diambil dari viva.co.id., yang mengatakan,

Ribuan orang membakar sebuah gereja di Desa Sukamakmu, Kecamatan Gunung Meriah, Kabupaten Aceh Singkil, Aceh, Selasa, 13 Oktober 2015. Aksi tersebut disinyalir akibat rumah ibadah tersebut tidak memiliki izin. Informasi diperoleh pada hari Selasa, pekan lalu, massa mengatasnamakan Pemuda Peduli Islam (PPI) Aceh Singkil menggelar unjuk rasa. Massa mendesak bupati untuk membongkar gereja yang tidak memiliki izin. Massa juga mengancam akan membongkar secara paksa jika tuntutan mereka tidak dituruti. Terkait hal tersebut, Bupati Aceh Singkil menggelar rapat bersama unsur Muspida, ulama, ormas Islam, serta para tokoh masyarakat pada Senin, 12 Oktober 2015. Dalam pertemuan tersebut dicapai kesepakatan 10 gereja dibongkar. Berdasarkan kesepakatan, pembongkaran gereja akan dimulai pada 19 Oktober hingga dua pekan. Selain itu, poin kesepakatan lainnya adalah rumah ibadah yang tidak dibongkar harus mengurus izin dalam kurun waktu selama enam bulan. Sebelumnya, masa dalam jumlah

\footnotetext{
${ }^{31} \mathrm{http}$ //gbis-online.org/gbis/online/berita-119-penutupan-pengrusakan-dan-atau-pembakaran-374-gerejadi-indonesia-tahun-1945--1997.html//14/10/2017///

${ }^{32} \mathrm{https}: / /$ calvinminadjaja.wordpress.com/2011/02/10/pembakaran-3-gereja-di-temanggung//14/10/2017//
} 
besar dengan menggunakan ikat kepala putih, membawa bambu runcing dan juga senjata tajam membakar gereja. Aksi pembakaran gereja yang biasa disebut undung-undung tersebut dilakukan sekitar pukul 11.30 pagi. Usai membakar gereja tersebut, massa kemudian bergerak ke lokasi lain. Puluhan polisi bersenjata lengkap berjaga di lokasi, namun jumlah massa yang cukup ramai, membuat pihak keamanan sulit mengendalikan pergerakan mereka. Camat Gunung Meriah, Deni Oskandar, membenarkan kejadian tersebut. Saat ini undung-undung ini telah hangus dibakar. "Sebuah undung-undung, kondisinya sekarang sudah hangus," kata Deni. Hingga saat ini situasi keamanan di Aceh Singkil masih mencekam. Massa masih melakukan pergerakan. Berdasarkan informasi, persoalan dipicu akibat ketidakpuasan warga dengan kesepakatan pemerintah kabupaten setempat terkait pembongkaran gereja. ${ }^{33}$

Apabila memperhatikan alasan massa membakar dan membongkar gereja di Aceh Singkil adalah karena diduga gereja tersebut tidak memiliki izin. Mungkin kita dapat bertanya, mengapa gereja tersebut tidak memiliki izin? Apakah karena orang-orang Kristen di wilayah itu tidak mau mengurus izin kepada pemerintah setempat? Menurut pendapat saya, kemungkinan karena regulasi yang diatur oleh pemerintah membuat kemudian gereja ini tidak memperoleh izin. Ketidakadilan atau diskriminasi seperti ini memang kerap dialami oleh kelompok minoritas di negeri ini. bahkan bukan hanya gereja saja namun agama atau kelompok minoritas yang lain pun mengalami hal serupa. Bahkan seolah-olah aparat hukum dan pemerintah tidak dapat berbuat banyak.

Akan tetapi sekali lagi seperti inilah persekusi yang dialami oleh gereja-gereja di Indonesia. Tidak sedikit gereja yang dibakar dalam sejarah berdirinya republik ini. Tidak sedikit orang Kristen yang kemudian mati martir karena persekusi yang sedemikian gencar dilakukan oleh kelompok mayoritas kepada gereja. Ada begitu banyak orang Kristen yang rela kehilangan harta benda, kampung halaman, rumah, hingga nyawa hanya demi mempertahankan imannya kepada Yesus Kristus. Meskipun sedemikian berat persekusi yang dialami oleh gereja, akan tetapi gereja tetap eksis di setiap tempat di republik ini.

Selanjutnya pengeboman yang dilakukan kepada sebuah Gereja Oikoumene di Samarinda, Kalimantan Timur. Seperti yang diberitakan oleh tempo.co, diberitakan, "Bom di Gereja Oikumene, Samarinda, Kalimantan Timur, merupakan aksi teror pertama di wilayah itu. Sebelumnya, Kota Samarinda terbilang jauh dari berbagai kasus teror. "Ini kasus pertama aksi teror di Samarinda," kata Kepala Kepolisian Resor Samarinda Komisaris Besar Setyobudi Dwi Putro, Minggu, 13 November 2016. Setyobudi mengatakan kerukunan di antara umat beragama terjalin harmonis di tengah masyarakat Samarinda. Selama ini,

\footnotetext{
${ }^{33}$ http://www.viva.co.id/berita/nasional/686672-kronologi-pembakaran-gereja-di-aceh//14/10/2017//
} 
menurut dia, tidak pernah ada permasalahan berbalut isu SARA yang menggelisahkan di Samarinda", 34

Akibat pengeboman ini, kemudian memunculkan banyak tanggapan dari lembaga bahkan tokoh-tokoh penting di republik ini. Tidak ketinggalan Persekutuan Gereja-gereja di Indonesia (PGI), yang juga mengeluarkan tanggapan sebagai berikut:

Terkait dengan ledakan bom yang menimpa jemaat HKBP di Gereja Oikoumene, Sengkotek, Kota Samarinda, Kalimantan Timur, Minggu 13 November 2016, Persekutuan Gereja-gereja di Indonesia (PGI) dalam siaran pers di Jakarta, 14/11, menyampaikan pesan-pesan sebagai berikut: Pertama, Kami menyampaikan keprihatinan mendalam dan simpati bagi para korban dan keluarganya. Kiranya Allah memberikan pemulihan bagi korban luka-luka terutama anak-anak. Kami menyampaikan dukacita yang mendalam kepada keluarga anak kekasih Olivia Intan Marbun, semoga keluarga mendapat penghiburan dan kekuatan-Nya. Kepada jemaat-jemaat di Gereja Oikoumene Samarinda kami mendoakan agar tetap tenang dan tekun dalam doa sekaitan dengan tragedi kemanusiaan yang terjadi. Kedua, Kami mengecam keras tindakan pengeboman ini, sama seperti tindakan-tindakan teror lainnya. Tindakan kekerasan, apapun bentuknya, tidak akan pernah bisa menyelesaikan masalah. Sebagai bangsa yang beradab, kita telah menyepakati bahwa kekerasan dan tindakan paksaan hanya boleh digunakan oleh negara, dan itu pun harus melalui prosedur hukum. Ketiga, Kami menghimbau kepada semua umat Kristen di mana pun berada untuk tetap tenang dan tidak perlu membangun opini liar, terutama di media sosial, yang dapat semakin menebar teror dan kebencian, baik bagi diri sendiri maupun masyarakat umum. Kami juga menghimbau umat untuk mempercayakan penanganan masalah ini kepada pemerintah dan aparat penegak hukum, dalam hal ini Kepolisian Republik Indonesia, sesuai prosedur dan mekanisme hukum yang berlaku di negara kita. Sebagai warga bangsa, kita harus tunduk dan menjunjung tinggi konstitusi dan jangan memaksakan kehendak melampaui mekanisme hukum. Kebenaran hukum haruslah dijunjung tinggi dan dihormati oleh umat Kristen sebagai warga bangsa. Kami mengajak umat Kristen terus mendoakan Pemerintah Republik Indonesia, untuk dapat menegakkan keadilan dan perdamaian di bumi Indonesia. Kami meminta perhatian kita semua untuk tetap setia mengambil bagian dalam pelayanan kasih dan pendamaian di mana pun dan dalam situasi yang bagaimana pun. Di tengah pencobaan ini, mari kita tetap membangun solidaritas kebangsaan bersama semua orang yang berkehendak baik, mewujudkan NKRI sebagai rumah bersama bangsa Indonesia. Keempat, Kepada Pemerintah, di bawah kepemimpinan Bapak Presiden Joko Widodo, kami meminta penanganan yang tegas, segera dan profesional atas peristiwa ini. Sudah banyak korban berjatuhan akibat teror dan tindak kekerasan di Republik ini. Kami meminta Pemerintah untuk tidak kalah terhadap semua bentuk tekanan kelompok-kelompok intoleran yang mengedepankan kehendaknya melalui cara-cara inkonstitusional, sekalipun mengatas-namakan agama. Kami juga menghimbau Pemerintah untuk dapat mencegah peristiwa sejenis dengan lebih dini menindak tegas bibit-bibit intoleransi dalam berbagai sikap dan ujaran kebencian yang akhir-akhir ini makin marak. Kelima, Kami mengajak seluruh komponen masyarakat Indonesia, khususnya para pimpinan agama, untuk tetap setia menanamkan dan menebarkan pesan-pesan perdamaian, kemanusian dan kebangsaan kepada umat masingmasing, karena untuk itulah, mestinya, agama-agama hadir di muka bumi ini. Segala

\footnotetext{
${ }^{34} \mathrm{https}$ ///nasional.tempo.co/read/819866/bom-di-gereja-oikumene-teror-pertama-disamarinda//14/10/2017//
} 
bentuk aspirasi dan perbedaan pendapat hendaknya dapat diselesaikan dengan jalan dialog, musyawarah atau melalui mekanisme hukum yang berlaku di negeri ini. ${ }^{35}$

Intinya, PGI sendiri begitu prihatin terhadap kejadian ini, namun PGI tetap mengajak seluruh warga jemaat supaya tidak terprovokasi. Sehingga gereja tetap menunjukkan substansi iman mereka, yakni tetap memperlihatkan dan mempraktikkan kasih bahkan kasih kepada musuh sekalipun. Sejarah panjang persekusi yang dialami oleh gereja-gereja di Indonesia menunjukkan betapa beratnya pergumulan yang dihadapi oleh gereja. Bahkan bukan hanya di Indonesia saja, melainkan di seluruh dunia. Tanpa iman yang kuat dan tanpa penyerahan diri total kepada Tuhan, maka mustahil gereja mampu mengalahkan itu semua. Perskusi memang sebuah ancaman yang dapat mengancam eksistensi gereja di dunia ini. Namun persekusi juga dapat dilihat sebagai ujian iman orang Kristen atau gereja di dunia ini. Karena kualitas iman kita akan ditentukan seberapa kuatnya kita menghadapi persekusi.

\section{Mengapa Gereja Mengalami Persekusi?}

Bukanlah sebuah pekerjaan yang mudah untuk menjawab pertanyaan di atas. Namun bukan berarti pertanyaan itu sama sekali tidak bisa dijawab. Meskipun dalam menjawabnya perlu sebuah kajian yang matang dan teliti bahkan perlu pemahaman yang cukup tentang konsep Alkitab terhadap topik ini. Dan memang dalam penelitian ini, penulis memilih untuk menggunakan Alkitab sebagai sumber primer untuk menjawabnya dengan mengutip beberapa pernyataan Yesus sendiri tentang pengikut-Nya kelak.

Tuhan Yesus sendiri sudah mengingatkan murid-murid-Nya termasuk gereja di sepanjang sejarah bahwa, "Jikalau dunia membenci kamu, ingatlah bahwa ia telah lebih dahulu membenci Aku daripada kamu. Sekiranya kamu dari dunia, tentulah dunia mengasihi kamu sebagai miliknya. Tetapi karena kamu bukan dari dunia, melainkan Aku telah memilih kamu dari dunia, sebab itulah dunia membenci kamu”, (Yoh. 15:18-19). Kemudian seolaholah diulang kembali oleh Yesus dalam Yohanes 17:14, “Aku telah memberitakan firman-Mu kepada mereka dan dunia membenci mereka, karena mereka bukan dari dunia, sama seperti Aku bukan dari dunia".36 Berdasarkan ayat-ayat di atas maka kemudian kita dapat menyimpulkan beberapa hal yang dapat menjadi alasan mengapa Gereja mengalami persekusi.

\footnotetext{
${ }^{35}$ http://www.hidupkatolik.com/2016/11/14/2959/siaran-pers-pgi-menyikapi-pemboman-gerejaoikoumene-di-samarinda//14/10/2017//

36 Bandingkan juga dalam 1 Yohanes 3:13, "Janganlah kamu heran, saudara-saudara, apabila dunia membenci kamu". Demikian juga apa yang dikatakan Yesus dalam Yohanes 7:7, "Dunia tidak dapat membenci kamu, tetapi ia membenci Aku, sebab Aku bersaksi tentang dia, bahwa pekerjaan-pekerjaannya jahat".
} 
Menurut Herman N. Ridderbos menegaskan, "Kata-kata pembukaan, 'jikalau dunia membenci kamu', menyajikan kebencian ini kepada murid-murid itu bukan hanya sebagai suatu kemungkinan tetapi sebagai suatu realitas yang tidak dapat mereka hindari karena mereka milik Yesus: 'ingatlah bahwa ia telah lebih dahulu membenci Aku daripada kamu'."37 Kemudian ditambahkan oleh Ridderbos,

Kedatangan Yesus, khususnya otoritas di mana Ia berperilaku dalam dunia sebagai Anak Allah, mempunyai lawan yang radikal dan sebagaimana adanya, monolitis (bdk.3:19dst., 7:7; 10:33, dst.), penyebab sesungguhnya dan sifat patut dicela yang lebih lanjut ditunjuk di ayat 21 dst. Kebencian itu juga akan diarahkan kepada murid-murid itu. Jika mereka "dari dunia" (ay.19), yaitu jika mereka membiarkan perilaku mereka dikondisikan bahwa mereka milik dunia, dunia tidak akan membenci mereka (7:7), tetapi akan mengasihi mereka, memandang mereka sebagai milik dunia, dan berhadapan dengan mereka sedemikian. Akan tetapi, murid-murid itu sebagai orang-orang yang telah dipanggil keluar dari dunia oleh Yesus dan dijadikan milik dan sahabat-sahabat-Nya ( $b d k$. ay. 1416), bukan milik dunia. Untuk alasan itulah dunia membenci mereka sebagai pembunuh kesukaan - sebagai pengikut-pengikut dari Dia yang terus-menerus menemukan kesalahan dengan dunia dan menyerahkan dunia kepada penghukuman Allah karena pemisahan dari Allah. ${ }^{38}$

Berdasarkan apa yang dikemukakan oleh Ridderbos di atas, maka kita kemudian mengajukan pertanyaan: Mengapa Gereja mengalami persekusi? Atau, mengapa dunia begitu membenci Gereja sehingga menganiaya dan mendiskriminasi Gereja? Setidaknya, dalam penjelasan di atas, ditemukan minimal ada tiga jawaban, yakni: (1) Karena Gereja adalah milik Kristus, di mana dunia telah lebih dahulu membenci dan menganiaya Kristus. (2) Karena Gereja tidak berasal dari dunia, sehingga tidak lagi dapat berkompromi dengan setiap kejahatan dan dosa yang dilakukan oleh dunia. (3) Karena Gereja tampil beda dari dunia, dalam arti ketika gereja menjadi saksi kepada dunia maka tentunya dunia tidak akan senang.

Poin ketiga di atas juga diperkuat oleh apa yang Yesus kemukakan dalam Yohanes 17:14. Menurut Colin G. Kruse, "By receiving the word of God that Jesus gave them, they, like Jesus himself, were now 'not of the world'. The world did not accept Jesus' word and hated those who did, just as it hated him $(7: 7 ; 15: 18-19 ; 24-25)$. In the Fourth Gospel very often the 'world', when it appears in opposition to Jesus as it does here, stands for those elements of the Jewish leadership who were antagonistic towards him, who sought to arrest him $(7: 30,32,44$; $8: 20 ; 10: 39 ; 11: 57)$ and wished to put him to death $(5: 18 ; 7: 1,19,25,8: 37,40 ; 11: 53)$ ". ${ }^{39}$ Intinya Kruse menegaskan bahwa dengan menerima firman Allah yang diberikan Yesus kepada mereka, maka

\footnotetext{
${ }^{37}$ Herman N. Ridderbos, Injil Yohanes: Suatu Tafsiran Teologis, Surabaya: Momentum, 2012, hlm. 568-
} 69.

${ }^{38}$ Ridderbos, hlm. 569.

${ }^{39}$ Colin G. Kruse, The Tyndale New Testament Commentaries: John, Surabaya: Momentum, 2007, hlm. 343-44. 
mereka sekarang seperti Yesus sendiri, sekarang mereka 'bukan dari dunia'. Dunia tidak menerima firman Yesus dan membenci orang-orang yang melakukannya, sama seperti membenci-Nya.

\section{Apakah persekusi bermanfaat bagi Gereja?}

Apabila melihat penjelasan panjang lebar di atas, maka tentunya kita akan diperhadapkan dengan kesulitan untuk melihat dan mengatakan bahwa persekusi itu bermanfaat bagi gereja. Asumsi ini dapat dibenarkan apabila melihat persekusi dari perspektif manusia atau melihatnya dalam "kacamata" jasmani. Mengapa?

Oleh karena justru melalui persekusi, justru Gereja banyak mengalami penderitaan dan penganiayaan. Tidak sedikit gereja yang harus dibakar, banyak Gereja yang juga harus dibunuh. Gereja tidak memiliki kebebasan untuk beribadah kepada Tuhan. Bahkan pemerintah pun kemudian mendukung kelompok-kelompok yang tidak senang dengan kekristenan. Oleh karena mereka tidak mau "menduakan" Tuhan dengan menyembah kepada kaisar yang sedang berkuasa. Sepintas memang seolah-olah persekusi justru menjadi kerugian besar bagi Gereja.

Akan tetapi apakah benar demikian? Ternyata tidak. Oleh karena ternyata justru persekusi banyak memberikan hal-hal positif kepada Gereja. Justru melalui persekusi, Gereja semakin dewasa dan mengerti tujuan kehadirannya di dunia. Dan berikut ini beberapa manfaat yang ditemukan dari persekusi yang dialami oleh Gereja:

Pertama, persekusi membuat Gereja dapat meneladani penderitaan yang telah dialami oleh Kristus atau lebih tepatnya Gereja telah melakukan kehendak Yesus. Seperti yang telah dikemukakan di atas, ketika Yesus berbicara seperti yang dicatat dalam Yohanes 15:18-19 hendak menegaskan bahwa kita tidak boleh heran ketika melihat dan mendengar Gereja hari ini dianiaya atau lebih tepatnya mengalami persekusi. Oleh karena itulah yang dikehendaki oleh Tuhan. Gereja yang mengalami persekusi adalah gereja yang masih setia menjaga Firman Tuhan dan tidak mau berkompromi dengan setiap dosa bahkan kejahatan yang dilakukan oleh dunia.

Kedua, persekusi membantu penyebarluasan Injil (Gereja) di dunia. Supaya Gereja tidak hanya terkonsentrasi pada satu wilayah saja, namun dapat menyebar ke seluruh bumi. Ketika Gereja terserak ke seluruh bumi, maka peluang atau kemungkinan untuk diberitakan ke seluruh bumi sangat terbuka.

Ketiga, persekusi terhadap Gereja dapat menjadi sarana Tuhan untuk menjadi saringan dan menyaring mana orang percaya sejati dan mana yang bukan. Ketika orang Kristen berada dalam kondisi yang baik, sehat, dan nyaman, maka tentunya hal itu tidak dapat dijadikan tolok 
ukur bahwa Dia telah memiliki iman yang sejati. Contoh yang paling konkret adalah apa yang dialami oleh Ayub dalam Perjanjian Lama. Tuhan mengizinkan Iblis untuk memberikan penderitaan yang mahadahsyat kepada Ayub untuk mengetahui siapa Ayub sebenarnya? Apakah dia adalah orang yang takut Tuhan? Ataukah dia hanyalah orang yang "pura-pura" takut Tuhan? Dan ternyata melalui persekusi yang dialami oleh Ayub dapat dilihat dengan jelas dan terang bahwa Ayub adalah umat Allah sejati. Demikian pula Gereja ketika diizinkan Tuhan mengalami yang namanya persekusi maka itu bertujuan untuk mengetahui mana yang benarbenar Gereja dan mana yang bukan Gereja.

Keempat, kualitas iman Gereja akan semakin ditingkatkan melalui persekusi. Untuk memperoleh sebuah emas yang murni, maka harus melalui proses peleburan terlebih dahulu. Emas itu harus dibakar, dipanaskan, dipukul, hingga nanti kita akan memperoleh emas murni yang bernilai. Demikian pula Gereja, supaya dapat memiliki kualitas iman atau rohani yang baik dan bernilai maka Gereja perlu melalui proses pembentukan panjang, dengan penderitaan, penganiayaan hingga persekusi. Supaya melalui semuanya itu, Gereja betul-betul dibentuk menjadi seseorang yang memiliki kualitas iman yang baik.

Kelima, persekusi terhadap Gereja dapat menolong Gereja untuk berbuah lebat. Persekusi dalam konteks ini dipahami seperti pohon yang tidak berbuah akan dibersihkan supaya kemudian menumbuhkan ranting-ranting yang baru yang dapat menghasilkan buah. Proses pembersihan itu tentu menimbulkan rasa sakit bagi pohon itu karena harus dipotong setiap ranting atau cabang yang tidak berbuah. Akan tetapi dampak yang ditimbulkan kemudian adalah pohon itu dapat berbuah lebat. Demikian pula Gereja, perlu untuk mengalami penderitaan, aniaya hingga persekusi supaya dapat memberikan buah yang lebat bagi kemuliaan Tuhan.

\section{Kesimpulan}

1. Persekusi tidak hanya terjadi atau dialami oleh masyarakat umum saja, namun ternyata juga dialami oleh Gereja Tuhan. Pendapat ini dibuktikan dengan bukti informasi yang diperoleh dari Alkitab, khususnya PB dan juga dalam literatur-literatur sejarah Gereja.

2. Gereja mengalami persekusi karena gereja memang berbeda dari dunia atau tidak berasal dari dunia. Karena Gereja telah dipilih dan dikhususkan oleh Tuhan untuk hidup berbeda dari dunia atau hidup seperti Kristus. Dan karena Kristus telah lebih dahulu mengalami hal itu, maka Gereja pun kemudian yang adalah pengikut Kristus juga mengalami hal yang serupa. 
3. Persekusi ternyata memiliki banyak manfaat bagi Gereja. Seperti yang telah diuraikan di atas, bahwa minimal ada lima manfaat. Seperti: persekusi membuat Gereja dapat meneladani penderitaan yang telah dialami oleh Kristus atau lebih tepatnya Gereja telah melakukan kehendak Yesus; persekusi membantu penyebarluasan Injil (Gereja) di dunia; persekusi terhadap Gereja dapat menjadi sarana Tuhan untuk menjadi saringan dan menyaring mana orang percaya sejati dan mana yang bukan; kualitas iman Gereja akan semakin ditingkatkan melalui persekusi; dan persekusi terhadap Gereja dapat menolong Gereja untuk berbuah lebat.

\section{Referensi:}

Berger, David; Wyschogrod, Michael. 1978. Jewish and "Jewish Christianity". New York: KTAV Publishing House.

Morris, Leon Injil Matius, Surabaya: Momentum.

Fernando, Ajith The NIV Application Commentary: Acts (From Biblical text..to Contemporary life), Zondervan, Grand Rapids, Michigan, 2009.

Henry, Matthew Tafsiran Surat 1 dan 2 Tesalonika, Surabaya: Momentum, 2015, hlm. 458.

Henry, Matthew Tafsiran Surat Ibrani, Surabaya: Momentum, 2016.

David E Aune. Word Biblical Commentary: Revelation 1-5. Dallas: Thomas Nelson, 1997.

Kistemaker, Simon J., Tafsiran Kitab Wahyu. Surabaya: Momentum, 2009.

Bauer's, Walter. A Greek-English Lexicon of The New Testament And Other Early Christian Literature (BDAG) Third Edition. Chicago: The University of Chicago Press, 2000. Diedit oleh: Frederick William Danker.

End, Th. Van den, Harta Dalam Bejana: Sejarah Gereja Ringkas, Jakarta: BPK Gunung Mulia, 2010.

Wellen, F.D., Riwayat Singkat Tokoh-tokoh Gereja. Jakarta: BPK Gunung Mulia, 1993.

Ridderbos, Herman N., Injil Yohanes: Suatu Tafsiran Teologis, Surabaya: Momentum, 2012.

Kruse, Colin G., The Tyndale New Testament Commentaries: John, Surabaya: Momentum, 2007.

http://nasional.kompas.com/read/2017/06/02/06260541/persekusi.fiera.lovita.diburu.diteror.d an.diintimidasi.// 20/09/2017//.

http://www.tribunnews.com/nasional/2017/06/01/lagi-seorang-remaja-diinterogasi-dan-

diancam-anggota-ormas-tertentu-gara-gara-statusnya-di-facebook//20/09/2017//.

https://id.wikipedia.org/wiki/Persekusi//27/09-2017//

https://indoprogress.com/2017/09/persekusi-dan-bahaya-menapaki-jalan-kristus-sebuah-

refleksi-terhadap-penyerbuan-kantor-ylbhi//27/09/2017//

https://indoprogress.com/2017/09/persekusi-dan-bahaya-menapaki-jalan-kristus-sebuahrefleksi-terhadap-penyerbuan-kantor-ylbhi//27/09/2017//

http://www.radioaustralia.net.au/indonesian/radio/onairhighlights/marak-kasus-kekerasanatas-nama-agama-indonesia-dilaporkan-ke-pbb/944098//14/10/2017//

http://www.bbc.com/indonesia/laporan_khusus/2012/07/120702_peran_negara_toleransi.sht $\mathrm{ml} / / 14 / 10 / 2017 / /$

http://gbis-online.org/gbis/online/berita-119-penutupan-pengrusakan-dan-atau-pembakaran374-gereja-di-indonesia-tahun-1945--1997.html//14/10/2017/// 
http://gbis-online.org/gbis/online/berita-119-penutupan-pengrusakan-dan-atau-pembakaran374-gereja-di-indonesia-tahun-1945--1997.html//14/10/2017///

https://calvinminadjaja.wordpress.com/2011/02/10/pembakaran-3-gereja-di-

temanggung//14/10/2017//

http://www.viva.co.id/berita/nasional/686672-kronologi-pembakaran-gereja-diaceh//14/10/2017//

https://nasional.tempo.co/read/819866/bom-di-gereja-oikumene-teror-pertama-disamarinda//14/10/2017//

http://www.hidupkatolik.com/2016/11/14/2959/siaran-pers-pgi-menyikapi-pembomangereja-oikoumene-di-samarinda//14/10/2017// 